\title{
RELATION TO FUNCTIONAL AND NUTRITIONAL STATUS AMONG HOSPITALIZED ELDERLIES
}

\author{
Stojchevska P. Viktorija, ${ }^{1}$ Jovanovska Tanja, ${ }^{1}$ Bogdanova Biljana, ${ }^{1}$ Belevska Maja, ${ }^{2}$ \\ Rajchanovska Domnika, ${ }^{1}$ Filov Izabela ${ }^{1}$ \\ ${ }^{1}$ Higher Medical School, University St. Kliment Ohridski - Bitola, Republic of Macedonia \\ ${ }^{2}$ Clinical Hospital Bitola, Republic of Macedonia
}

Primljen/Received 19. 03. 2018. god.

Abstract: Introduction: Adding years to life is a great achievement when this is accompanied by a good level of health and well-being and independence. Major indicators for prediction mortality risk in older adults are the nutrition status and physical functional ability. The aim of this study is to present the nutritive and functional status among institutionalized elderlies and the relatedness with certain risk factors. Material and methods: Cross-sectional study has been conducted at certain nursing homes with participation of individuals over 60 years old. As for the research Scale of Daily Living Activities (ADL) has been used to present the functional capacity of the elderly and MNA has been used to detect the nutrition status. Results: The results from the research conducted among elderlies have shown the following socio-demographic characteristics: out of 127 participants, most of them were females- $77 \%$ and $69 \%$ at the age between 75 and 84 . Most of the elderlies (in $68 \%$ ) have completed secondary education. The results from MNA have shown that $69,2 \%$ are well- nourished, $27,6 \%$ are at risk for malnutrition and 3,2\% are malnourished. There is a relatedness of the nutrition status with the gender $(\mathrm{p}<0,001)$ and the level of education $(\mathrm{p}<$ $0,001)$.ADL scale among 127 elderly participants has shown that $37 \%$ are independent, $45 \%$ are with a moderate impairment and $18 \%$ are with severe functional impairment. In comparison with the females, the males show higher level of functional ability in all ADL components except the continence. Conclusion: The results from the research have shown that the nutrition status among elderlies is satisfactory, emphasizing the factors such as gender, education level and functional ability as key points for the level of nutrition status at the elderlies.

Key words: malnutrition, functional capacity, elderly.
Prihvaćen/Accepted 10. 06. 2018. god.

\section{INTRODUCTION}

Aging among population worldwide is quite present regardless of its level of development. Even though the progression is higher in the developed countries yet the population aging includes those countries where the young people is present as well (1). In Macedonia the presence of people over 60 years in 2012 expressed in percentage is $17,5 \%$ and those over the age of 80 is $2,3 \%$ from the total number of population.

Adding years to life is a great achievement when this is accompanied by a good level of health and well-being and independence. Nevertheless ageing increases the dependence of other people due to reduction of the level of functional independence (2).

Major indicators for prediction mortality risk in older adults are the nutrition status and physical functional ability (3). A decline in functional status is a profound predictor of mortality (4). The death rate increases from $8 \%$ in individuals with no disability, to $15 \%$ with one or more Instrumental Activities of Daily Living (IADL) disabilities, to $21 \%$ in persons with one or two ADL dependencies, and up to $37 \%$ in those with five or six ADL dependencies during a 2-year period (5). Many studies have shown that malnutrition among elderly increases the death rate opposite to elderly with good nutrition status (5-10).

Nursing homes are the ones offering proper care for elderly of 80 years and above (11). The inability to live at home is intensifying the necessity of institutional care of elderly offered by the nursing homes (12). Nursing homes across Europe provide care for 2 to $10 \%$ of the elderly $(13,14)$. Several studies have shown that the institutionalized female elderly register higher prevalence of malnutrition in terms of elderly people in general (15-18). 
Mini Nutritional Assessment (MNA) is s method used for identification of malnutrition risk among elderly. The MNA is a simple, low cost and noninvasive method that can be done at bedside (19). Added MNA scores allow one to screen the elderly who have an adequate nutritional status, those who are at risk of malnutrition and those who are malnourished.

The aim of this study is to present the nutritive and functional status among institutionalized elderlies and the relatedness with certain risk factors.

\section{MATERIAL AND METHODS}

Cross-sectional study has been conducted at certain nursing homes in R. Macedonia with participation of individuals over 60 years old. Before the start of the research, the author has provided consent from the relevant authorities of the institutions. Each participant was explained in details about the aim of the research as well as the anonymity and the voluntary aspect of this study. Before the beginning of the anonymous questionnaire a verbal and official /sighed consent has been provided by each participant (addition 1). Out of 148 elderlies the research has been conducted to 127 as of the absence or inability to participate due to mental disorder.

\section{Nutritional Status}

MNA (addition 2) has been used to detect the nutrition status, which is composed of 18 items such as: anthropometry: body mass index (weight in kilograms / Height in Meters x Height in Meters), calf circumference (measuring the calf at the widest part) and arm circumference (the distance between the acromial surface of the scapula (bony protrusion surface of upper shoulder) and the olecranon process of the elbow (bony point of the elbow) on the back of the arm.), dietary (number of meals, autonomy to feed, water and food ingestion), and global assessment (medicines, residence, mobility, dementia, stress, how does the patient consider his/her health status and nutritional status). The interpretation of the results is done based on the total score such as: 24 and above are considered as adequate nourished, 17 to 23,5 are considered as individuals at risk of malnutrition and 17 and below are considered to be malnourished (7).

\section{Addition 1}

\section{Consent form for participants}

1. I understand that my participation is voluntary and that I am free to withdraw at any time without giving any reason.

2. I understand that confidentiality and anonymity will be maintained and it will not be possible to identify me in any publications

Patients name

Signature

Table 1. Variable associated with functional activates, gender and BMI

\begin{tabular}{|l|c|c|c|c|c|c|}
\hline ANOVA \\
\hline Source of Variation & SS & $\boldsymbol{d} \boldsymbol{f}$ & MS & $\boldsymbol{F}$ & $\boldsymbol{P}$-value & $\boldsymbol{F}$ crit \\
\hline Between Groups & 253.5 & 2 & 126.75 & 6.019789 & $\mathbf{0 . 0 2 1 8 9 9}$ & 4.256495 \\
\hline Within Groups & 189.5 & 9 & 21.05556 & & & \\
\hline Total & 443 & 11 & & & & \\
\hline
\end{tabular}

Table 2. Factors linked with the nutrition status among hospitalized elderly in R. Macedonia

\begin{tabular}{|l|c|c|c|c|}
\hline & $\mathrm{N}$ & $\begin{array}{c}\text { Risks with malnutrition } \\
\text { and with malnutrition }\end{array}$ & Well nourished & P value \\
\hline Registered illnesses less than 3 & 121 & $\begin{array}{c}31(35 \%) \\
46(65 \%)\end{array}$ & $\begin{array}{c}14(32 \%) \\
30(68 \%)\end{array}$ & 0,216 \\
Registered illnesses more than 3 & & $38(54,2 \%)$ & $21(60 \%)$ & 0,689 \\
\hline Moderate physical activity & 105 & $32(45,8)$ & $14(40 \%)$ & $<0,0001$ \\
Physical inactivity & & $45(52,9 \%)$ & $5(11,9 \%)$ & $32(88,1 \%)$ \\
\hline Dependent and partly dependent & 127 & $40(47,1 \%)$ & & $<$ \\
Independent & & & \\
\hline
\end{tabular}




\section{Mini Nutritional Assessment MNA $^{\circledR}$}

\section{Nestlé NutritionInstitute}

\begin{tabular}{|c|c|c|c|}
\hline Last name: & & & \\
\hline$\underline{\text { Sex }}$ & Weight, kg: & Height, cm: & Date: \\
\hline
\end{tabular}

Complete the screen by filling in the boxes with the appropriate numbers.

Add the numbers for the screen. If score is 11 or less, continue with the assessment to gain a Malnutrition Indicator Score.

\section{Screening}

A Has food intake declined over the past 3 months due to loss of appetite, digestive problems, chewing or swallowing difficulties?

$0=$ severe decrease in food intake

$1=$ moderate decrease in food intake

$2=$ no decrease in food intake

B Weight loss during the last 3 months

$0=$ weight loss greater than $3 \mathrm{~kg}$ ( $6.6 \mathrm{lbs})$

$1=$ does not know

$2=$ weight loss between 1 and $3 \mathrm{~kg}$ ( 2.2 and $6.6 \mathrm{lbs})$

$3=$ no weight loss

C Mobility

$0=$ bed or chair bound

1 = able to get out of bed / chair but does not go out

2 = goes out

D Has suffered psychological stress or acute disease in the past 3 months?

$0=$ yes

$2=$ no

E Neuropsychological problems

$0=$ severe dementia or depression

$1=$ mild dementia

$2=$ no psychological problems

F Body Mass Index (BMI) (weight in $\mathrm{kg}$ ) / (height in $\mathrm{m}^{2}$ )

$0=$ BMI less than 19

$1=$ BMI 19 to less than 21

$2=$ BMI 21 to less than 23

$3=$ BMI 23 or greater

Screening score (subtotal max. 14 points)

12-14 points: Normal nutritional status

8-11 points: At risk of malnutrition

0-7 points: Malnourished

For a more in-depth assessment, continue with questions $G \cdot R$

\section{Assessment}

G Lives independently (not in nursing home or hospital) $1=$ yes $\quad 0=$ no

H Takes more than 3 prescription drugs per day

$0=$ yes $\quad 1=$ no

\begin{tabular}{l}
\hline Pressure sores or skin ulcers \\
$0=$ yes $\quad 1=$ no
\end{tabular}

References

1. Vellas B, Villars H, Abellan G, et at. Overview of the MNA - Its History and Challenges. J Nutr Health Aging. 2006; 10:456.465

2. Rubenstein LZ, Harker JO, Salva A, Guigoz Y, Vellas B. Screening for Undernutrition in Geriatric Practice: Developing the Short-Form Min Nutritional Assessment (MNA-SF). J. Geront. 2001; 56A: M366-377

3. Guigoz Y. The Mini-Nutritional Assessment (MNA) Review of the Literature - What does it tell us? J Nutr Health Aging. 2006; 10.466-487.

(2) Societté des Produits Nestlé, S.A., Vevey, Switzerland, Trademark Owners

ONestlé, 1994, Revision 2009. N67200 12/99 10M

For more information: wwwmna-elderly.com

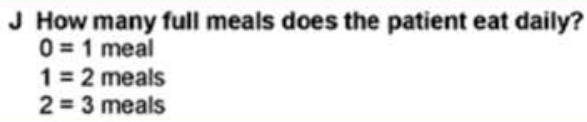

$\mathrm{J}$ How many full meals does the patient eat daily?

$0=1$ meal

$1=2$ meals

$2=3$ meals

K Selected consumption markers for protein intake

- At least one serving of dairy products (milk, cheese, yoghurt) per day

- Two or more servings of legumes or eggs per week

- Meat, fish or poultry every day

$0.0=$ if 0 or 1 yes

$0.5=$ if 2 yes

$1.0=$ if 3 yes

$\mathrm{L}$ Consumes two or more servings of fruit or vegetables per day?

$0=$ no $\quad 1=$ yes

M How much fluid (water, juice, coffee, tea, milk...) is

consumed per day?

$0.0=$ less than 3 cups

$0.5=3$ to 5 cups

$1.0=$ more than 5 cups

\section{$\mathrm{N}$ Mode of feeding}

$0=$ unable to eat without assistance

1 = self-fed with some difficulty

2 = self-fed without any problem

O Self view of nutritional status

$0=$ views self as being malnourished

$1=$ is uncertain of nutritional state

$2=$ views self as having no nutritional problem

P In comparison with other people of the same age, how does the patient consider his / her health status?

$0.0=$ not as good

$0.5=$ does not know

$1.0=$ as good

$2.0=$ better

Q Mid-arm circumference (MAC) in cm

$0.0=$ MAC less than 21

$0.5=$ MAC 21 to 22

$1.0=$ MAC 22 or greate

$R$ Calf circumference (CC) in $\mathbf{~ c m}$

$0=\mathrm{CC}$ less than 31

$1=\operatorname{CC} 31$ or greater

Assessment (max. 16 points)

Screening score

Total Assessment (max. 30 points)

Malnutrition Indicator Score

24 to 30 points $\quad \square \quad$ Normal nutritional status

17 to 23.5 points

Less than 17 points

At risk of malnutrition

Malnourished 


\section{Functional capacity}

As for the research Scale of Daily Living Activities (ADL) has been used to present the functional capacity of the elderly. It is consisted of activities demonstrating daily living independency. The scale is assessed with values 1 - for independent and 0 - for dependence. The score of 6 indicated complete independence, score 4 indicated moderate impairment and 2 and below indicate severe functional imparement $(20,21)$.

Data were analyzed with the Statistical Package for Social Science (SPSS), version 19.0. The analysis involved elderly with malnutrition and risk of it, using Pearson correlation coefficient with significance level of $5 \%$. Poisson regression has been performed, presenting the reasons for raw and adjusted prevalence and their respective confidence intervals at 95\% (CI 95\%). Variables that were associated with significance level $(p<0.10)$ were included in the model.

\section{RESULTS}

The results from the research conducted among elderlies have shown the following socio-demographic characteristics: out of 127 participants, most of them were females- $77 \%$ and $69 \%$ at the age between 75 and 84 . Most of the elderlies (in 68\%) have completed secondary education.

As for the estimation of their own health condition, most of the participants (in 47\%) have stated that their health is good and $41 \%$ of the elderlies estimated their health condition as poor. $76 \%$ of them use more than 3 medications a day and $17 \%$ of them use less than 3 medications a day. As of the results at $61 \%$ of the participants less than 3 diseases has been registered as presents and 34\% reported more than 3 diseases.

According to BMI $19 \%$ are with low wight, $33 \%$ are with a normal weight, $31 \%$ are overweight and $17 \%$ are obese. Mid value of BMI is 22,3 with statistical significance between males and females $(\mathrm{p}<0.001)$.

The results from MNA have shown that $69,2 \%$ are well- nourished, $27,6 \%$ are at risk for malnutrition and $3,2 \%$ are malnourished. There is a relatedness of the nutrition status with the gender $(p<0,001)$ and the level of education $(p<0,001)$.

ADL scale among 127 elderly participants has shown that $37 \%$ are independent, $45 \%$ are with a moderate impairment and $18 \%$ are with severe functional impairment. In comparison with the females, the males show higher level of functional ability in all ADL components except the continence. From the results of the chosen items (functional activates, BMI and gender) represented in the table no 1 we have: independent $(37 \%)$, moderate impairment (45\%) and severe functi- onal impairment $(23 \%)$. According to the represented results we have significant differences between the groups $(\mathrm{p}<0,05)$.

Regarding the variables related to elderly health, it has been found that presence of more than 3 diseases, physical inactivity and functional capacity for ADLs was associated to nutritional status. Table 2 presents PR (Prevalence Rations) of independent variables and their confidence intervals. It was observe as a result of the multivariate analysis, that only the variable functional capacity for ADL was statistically significant.

\section{DISCUSSION}

This research presents the socio- demographic characteristics, health, nutritive status, activity daily living among institutionalized elderlies. As for the study most of the participants expressed in percentage were females at the age between 75 and 84 . Most of the participants have completed secondary education. The participants that were mostly included in this research estimate their own health condition as good and most of them use more than 3 medications a day, and for most of them less than 3 diseases are registered.

Self-evaluating research among elderlies in Korea has shown that $78 \%$ of the people have registered an ilIness that is related with the estimation of their own health (22).

The morbidity in this research can be explained with the fact that the institutionalizing of the elderlies is mostly a result of the presence of illness and inability for different types of care to this population.

According MNA scores 27,6\% from the participants were at risk of malnutrition and $3.2 \%$ were registered as malnourished. Those results were with a lower range than most of the international studies, whereas the results from 32 multinational studies including 6,821 institutionalized elders indicated that the prevalence of malnutrition and its risk were $5-71 \%$ and $27-70 \%$ respectively (17). A study conducted at a nursing homes in Spain presented a prevalence of $2,8 \%$ of participants are with malnutrition and $37,3 \%$ are at risk of malnutrition. (23).

The nutrition status among participants is most probably registered as good due to the exclusion of the severely ill and elderlies suffering with dementia, during the conduct of this research.

In this study the nutrition status has shown relatedness also with the gender and the level of education among hospitalized elderlies.

A research conducted in Brazil has shown that the nutritional status was associated with gender, education, where ålderly men had a greater potential for malnutrition and malnutrition risk (24). 
High proportion of elderly with low weight mostly man was found in the research done by Menezes and Marucci (25). As for the education and nutritional status a relatedness was indentified in a other studies conducted in Brazil (26). As for this study along with the aforementioned studies conducted in Brazil most of the examined are registered with a low level of education. This result may be related to low socioeconomic status and poor access to information. Barreto et al.also suggests that low education is a risk factor for low weight, explained by lower income in old age (27).

The results of ADL scale have shown that most of the participants are able to perform their basic daily activities, comparing that males show higher percentage of independence in all components of ADL except the continence, than females.

Similar results were shown with the study conducted at nursing homes in Lebanon where the males have shown higher level of functional ability compared to the females (28).

This study has also shown relatedness of the nutrition status and presence of more than 3 diseases among participants which is confirmed with the results of the research of Stratton RJ whereas the results shown that Somatic diseases may also increase the risk of malnutrition (29).

Participants included in this research show moderate physical activity and physical inactivity in the hospitalized elderly. Study conducted by Walid Kamal M. Abdelbasset approved beneficial effects of physical activity on depression status and pain in elderly people (30).

The results have shown a relation with the nutrition status and the functional capacity of ADL same as the research conducted in Brazil where it has been observed that dependent or partially dependent individuals for performing ADLs are approximately 1.6 times more malnourished or at risk of malnutrition than independent individuals (24).

Nutrition status among institutionalized elderly affects the impaired functional capacity, appearing whether as a cause of a consequence. It is possible that nutritional status is an important factor in maintaining functional capacity, due to some aspects such as the lowest level of physical activity and muscle atrophy (31).

\section{CONCLUSION}

The results from the research have shown that the nutrition status among elderlies is satisfactory, emphasizing the factors such as gender, education level and functional ability as key points for the level of nutrition status at the elderlies.

MNA and ADL are both simple and noninvasive scales that can easily be administered among hospitalized elderlies. Simple applying can be effective and economic manner of identification of persons that are in need of intervention.

\section{DECLARATION OF INTEREST}

The autors declare that there are no conflicts of interests.

\section{Licensing}

This work is licensed under a Creative Commons Attribution 4.0 International (CC BY 4.0) License.

\title{
Sažetak
}

\section{ODNOS FUNKCIONALNOG I NUTRITIVNOG STATUSA KOD STARIH}

\author{
Stojchevska P. Viktorija, Jovanovska Tanja, ${ }^{1}$ Bogdanova Biljana, ${ }^{1}$ Belevska Maja, ${ }^{2}$ \\ Rajchanovska Domnika, ${ }^{1}$ Filov Izabela \\ ${ }^{1}$ Higher Medical School, University St. Kliment Ohridski - Bitola, Republic of Macedonia \\ ${ }^{2}$ Clinical Hospital Bitola, Republic of Macedonia
}

Uvod: Starenje je izrazito uspešno kada je praćeno dobrim nivoom zdravlja, blagostanja i nezavisnosti. Glavni indikator za predviđanje rizika mortaliteteta kod starijih ljudi je nutritivni status i funkcionalna fizička sposobnost. Cilj ove studije bio je da se predstavi nutritivni i funkcionalni status među institucionalizovanih starih osoba u korelaciji sa određenim faktorima rizika. Materijal i metode: studija slučajeva i kontrola je sprovedena u određenim staračkim domovima sa učešćem pojedinaca koji su imali preko 60 godina. Za analizu je uzeta Merna skala dnevnih aktivnosti (ADL) koja je prezentovala funkcionalni kapacitet starih lica kao i MNA koja je određivala nutritivni status. Rezultati: Rezultati ove studije pokazali su sledeće demografske karakteristike: od 127 paciejanta, večina je bila ženskog pola - 77\% i 69\% između 75-84 godine. Većina starih $(68 \%)$ je imala srednju stručnu spremu. Rezultati MNA pokazali su da je $69,2 \%$ ispitanika bilo dobro hranjeno, $27,6 \%$ je bilo pod rizikom od malnutricije i $3,2 \%$ je bilo pothranjeno. Postoji povezanost između nutritivnog statusa i pola $(\mathrm{p}<0,001)$ i nivoa obrazovanja $(p<0,001)$. ADL skala je od 127 ispitanika pokazala da je $37 \%$ nezavisno, $45 \%$ sa srednjim oštećenjima, kao i $18 \%$ sa ozbiljnim funkcionalnim 
oštećenjima. U poređenju sa ženama, muškarci su pokazali viši nivo funkcionalne sposobnnosti u svim ADL komponentama, osim kontinencije.

Zaključak: Rezultati ove studje pokazali su da je nutritivni status među starim licima zadovoljavajući i

\section{REFERENCES}

1. Ageing in the twenty-first century: a celebration and a challenge. United Nations Population Fund (UNFPA) and Help Age International, 2012.

2. Tolson D, Rolland Y, Andrieu S, Aquino JP, Beard $\mathrm{J}$, Benetos A, et al. International Association of and Geriatrics: a global agenda for clinical research and quality of care in nursing homes. J Am Med Dir Assoc. 2011; 12(3): 184-9.

3. Tsai AC, Lee LC, Wang JY. Complementarity of the mini-nutritional assessment and activities of daily living for predicting follow-up mortality risk in elderly Taiwanese. Br J Nutr. 2013; 109(4): 658-66.

4. Thomas DR, Kamel H, Azharrudin M, Ali AS, Khan A, Javaid U, et al. The relationship of functional status, nutritional assessment,and severity of illness to in-hospital mortality. J Nutr Health Aging. 2005; 9(3): 169-75.

5. Manton KG. A longitudinal study of functional change and mortality in the United States. J Gerontol Soc Sci. 1988; 43(5): S153-61.

6. Beck AM, Ovesen L, Osler M. The "Mini Nutritional Assessment" (MNA) and the "Determine Your NutritionalHealth" Checklist (NSI Checklist) as predictors of morbidity and mortality in an elderly Danish population. Br J Nutr. 1999; 81(1): 31-6.

7. Persson MD, Brismar KE, Katzarski KS, Nordenström J, Cederholm TE. Nutritional status using mini nutritional assessment and subjective global assessment predict mortality in geriatric patients. J Am Geriatr Soc. 2002; 50(12): 1996-2002.

8. Donini LM, Savina C, Rosano A, De Felice MR, Tassi L, De Bernardini L et al. MNA predictive value in the follow-up of geriatric patients. J Nutr Health Aging. 2003; 7(5): 282-93.

9. Vellas B, Guigoz Y, Garry RJ, Nourhashemi F, Bennahum D, Lauque Set al. The Mini Nutritional Assessment (MNA) and its use in grading the nutritional state of elderly patients. $\mathrm{Nu}$ trition.1999; 15(2): 116-22.

10. Chan M, Lim YP, Ernest A, Tan TL. Nutritional assessment in an Asian nursing home and its association with mortality. J Nutr Health Aging. 2010; 14(1): 23-8.

11. Long-term Care for Older People. The OECD Health Project [Internet]. OECD Publishing; 2005 Jun 30; Available from: http://dx.doi.org/10.1787/9789264015852-en.

12. Akner G: Analysis of multi morbidity in individual elderly nursing home residents. Development of a multi morbidity matrix. Arch Gerontol Geriatr. 2009; 49(3): 413-19.

13. Lobo A, Santos P, Carvalho J, Mota J. Relationship between intensity of physical activity and health-related quality of life in Portuguese institutionalized elderly. Geriatr Gerontol Int. 2008; 8(4): 284-90.

14. Drageset J, Natvig GK, Eide GE, Clipp EC, Bondevik $\mathrm{M}$, Nortvedt MW, et al. Differences in health-related quality of da skreće pažnju na pol, nivo obrazovanja i funkcionalne sposobnosti kao ključne tačke u nutritivnom statusu starih.

Ključne reči: malnutricija, funkcionalni kapacitet, stari.

life between older nursing home residents without cognitive impairment and the general population of Norway. J Clin Nurs. 2008; 17(9): 1227-36.

15. Donini LM, Scardella P, Piombo L, Neri B, Asprino R, Proietti AR, et al. A malnutrition in elderly: Social and economic determinants. J Nutr Health Aging. 2013; 17(1): 9-15.

16. Vandewoude M, VanGossum A.Nutritional screening strategy in nonagenarians: the value of the MNA-SF (mini nutritional assessment short form) in NutriAction. J Nutr Health Aging. $2013 ; 17(4)$ : 310-4.

17. Guigoz Y. The mini nutritional assessment (MNA) Review of the literature - What does tell us?. J Nutr Health Aging. 2006; 10 (6): 466-87.

18. Tsai AC, Ho CS, Chang MC. Assessing the prevalence of malnutrition with the Mini Nutritional Assessment (MNA) in a nationally representative sample of elderly Taiwanese. J Nutr Health Aging. 2008; 12(4): 239-43.

19. Guigoz Y, Garry JP. Mini nutritional assessment: A practical assessment tool for grading the nutritional state of elderly patients. Facts Res Gerontol. 1994; 4(2): 15-59.

20. Morris JN, Fries BE, Morris SA. Scaling ADLs within the MDS. J. Gerontol. A Biol.Sci.Med.Sci. 1999; 54:(11) M546-53.

21. Snowden M, McCormick W, Russo J, Srebnik D, Comtois K, Bowen J, Teri L et al. Validity and responsiveness of the minimum data set. J. Am. Geriatr. Soc. 1999; 47(8): 1000-4.

22. Woo E, Han C, Jo SA, Park MK, Kim S, Kim E at all. Morbidity and related facgors among elderly people in South Korea: results from the Ansan Geriatric (AGE) cohort study. BMC Public Health. 2007; 7:10.

23. Serrano-Urrea R, Garcia-Mesequer MJ. Malnutrition in an elderly population without cognitive impairment living in nursing homes in Spain: study of prevalence using the Mini Nutritional Assessment test. Gerontology. 2013; 59(6): 490-8.

24. Amorim Sena Pereira ML, de Almeida Moreira P, Cunha de Oliveira C, Carneiro Roriz AK, Teresópolis Reis Amaral M, Lima Mello A at all. Nutitional status of institutionalized elderly Brazilians: a study with the MNA. Nutr Hosp. 2014; 31(3): 1198-204.

25. de Menezes TN, Marucci MD. Avaliaçno antropométrica de idosos residentes em Instituiçtes de Longa PermanLncia de Fortaleza-CE. Rev Bras. Geriatr Gerontol. 2010; 13(2): 235-43.

26. Pereira Machado RS, Santa Cruz Coelho MA. Risk of malnutrition among Brazilian institutionalized elderly: a study with the Mini Nutritional Assessment (MNA) questionnaire. J Nutr Health Aging. 2011; 15(7): 532-5.

27. Barreto SM, Passos VMA, Lima-Costa MFF. Obesity and underweight among Brazilian elderly: the Bambuí Health and Aging Study. Cad Saude Publica. 2003; 19(2): 605-12. 
28. Doumit JH, Nasser RN, Hanna DR. Nutritional and health status among nursing home residents in Lebanon: comparison across gender in a national cross sectional study. BMC Public Health. 2014; 14:629.

29. Stratton RJ, Green CJ, Elia M. Disease-related Malnutrition: an evidencebased approach to treatment. CABI Publishing. 2003; 93-155.

\section{Correspondence to / Autor za korespondenciju}

Viktorija Prodanovska-Stojchevska

Str. Prevalec no. 21

7000 Bitola, Republic of Macedonia

Tel: +38970392955
30. Abdelbasset WK, Subash GN. Relationship between physical activity and health-related quality of life in elderly people: a cross section study. Sanamed. 2017; 12(2): 87-92.

31. Moreira PL, Villas Boas PJF. Avaliaçno nutricional e capacidade functional de idosos institucionalizados em Botucatu/SP. Geriatria Gerontologia. 2011; 5(1): 19-23. 